\title{
Business Incubation Model based on Productive Zakatfor Economic Recovery SMEs of Post COVID-19
}

\author{
Nadia Nuril Ferdaus, Fatimatuz Zahrati \\ Universitas Gadjah Mada
}

\author{
Ahmad Hidayatullah \\ Istanbul Sabahattin Zaim University \\ Paper to be presented at the $4^{\text {th }}$ International Conference of Zakat (ICONZ) \\ 7-8 October 2020, Surabaya, Indonesia
}

\begin{abstract}
The effect crisis of COVID-19 in economic sector brings an extremely worries for the middle to bottom economic class. The effort of small and medium size enterprises as a backbone of national economic suffered a blow for economic setbacks. This paper aims to formulate the innovation of business model based on community development as an effort to countermeasure an effect of society economic crisis in real sector with formulating of business model innovation based on productive zakat to restore the economy of SMEs affected by the pandemic. This research is qualitative research with descriptive approach. The data used are primer and secondary data and the data collection techniques that carried out by researcher are an interviews with beneficiaries as leaders in the business incubation projects that have been carried out, while secondary data from literature review and business report documents of mustahik. The model of business incubator based on zakat productive has enarmous potential in restoring the economics of micro-small and medium sized entreprises (SMEs) that have been affected by the pandemic.
\end{abstract}

Keyword: Business Incubator, Productive Zakat, SMEs, COVID-19.

\section{INTRODUCTION}

Corona Virus Disease (COVID-19) was first discovered in Wuhan, China. Since the spread of the virus has prompted the World Health Organization (WHO) to declare it a world pandemic. The spread that happened so fast has led to the emergence of various policies taken by the government. Starting from the appeal for social distancing or maintaining distance from social crowds, to the PSBB (Large-Scale Social Restriction) policy, they believed that it can massively slow the spread of the COVID-19 disease. The policies to tackle the spread of the virus globally have multiplier effects on various aspects of people's lives, not only in terms of health, but also in other aspects of life, such as an economy that is threatened with the global financial crisis.
The Organization for Economic Cooperation and Development (OECD) in its report stated that this pandemic has implications for the threat of a major economic crisis marked by the cessation of production activities in many countries (OECD 2020). Consider from the economic conditions in Indonesia, which is largely dominated by the Micro, Small and Medium Enterprises (MSMEs) industrial sector, of course this will also affect the existence of MSMEs in Indonesia. Based on the report from the Ministry of Cooperatives, MSMEs, which are referred to as the backbone of the national economy, show that as many as 64,194,057 registered MSMEs are able to absorb 116,978,631 workers or around $97 \%$ of the total Indonesian workforce (KEMENKOP, 
2018). The data above is strengthened by the data released by the BAZNAS Strategic Studies Center regarding the decline in the income level of MSMEs on a national scale in Figure 1 (Puskas BAZNAS 2020a):

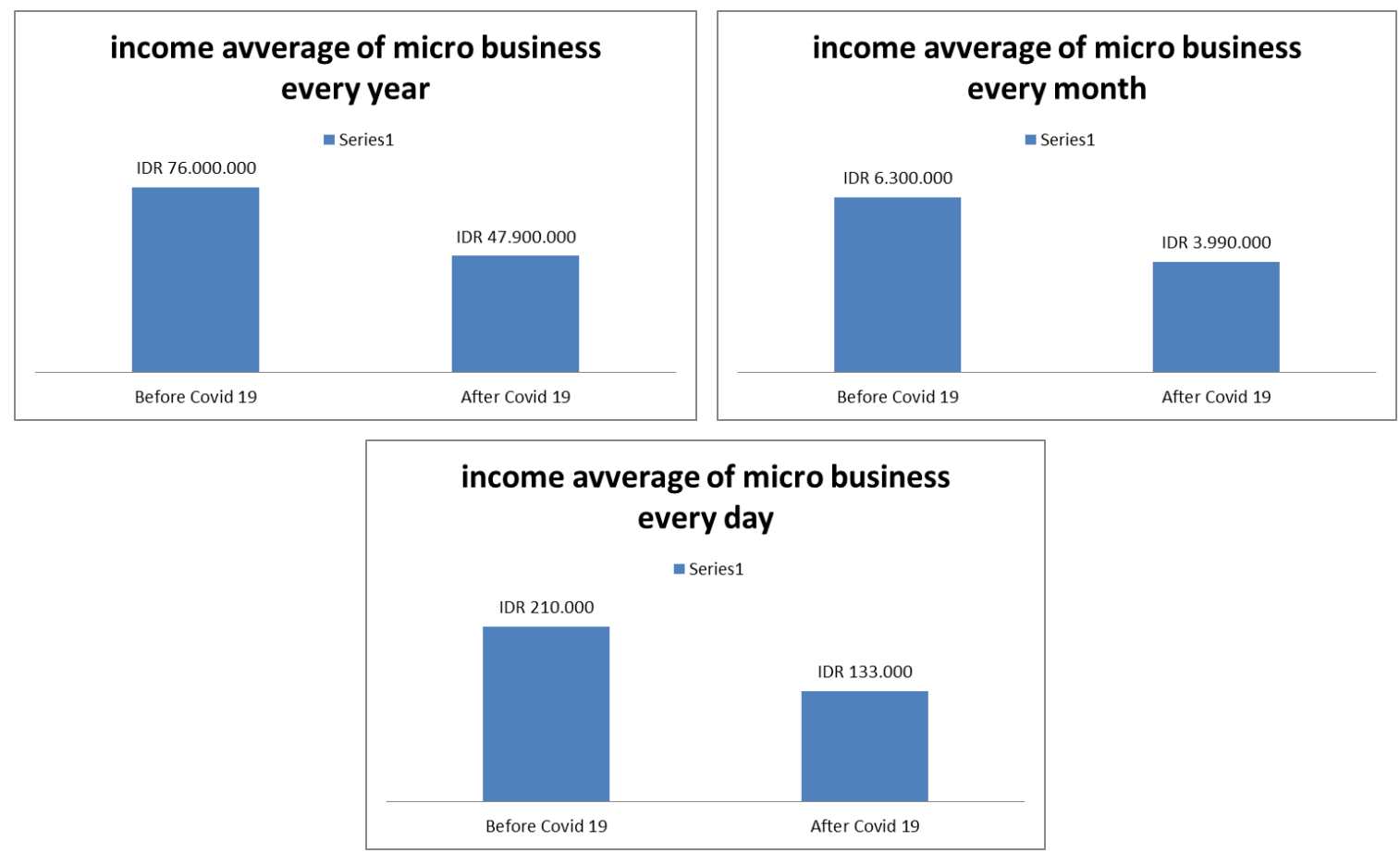

Figure 1. The Projection Data Impact of the Covid-19 Health Crisis on MSMEs

Source: (Puskas BAZNAS 2020)

The impact of the COVID-19 crisis on the economic sector brings tremendous concern to the lower middle-class economy. As in the study conducted by Ascarya (2020) which shows that the economic groups of people who are right above the poverty line are very vulnerable to falling below this line due to the effects of the pandemic economic crisis. Of course, it can be an exacerbate conditions by increasing the level of poverty globally.

Facing various polemics of the COVID-19 pandemic crisis threatens the country's fiscal instruments in the potential to run into deficits. As data from the Ministry of Finance of the Republic of Indonesia, which has added to the list of additional spending and funding for the 2020 State Budget for handling COVID-19 amounts to IDR 405.1 trillion. On the other hand, due to the weakening economic conditions resulting in a decrease in state income by $10 \%$ from the decrease in tax revenue, both $\mathrm{PPh}$ and $\mathrm{PNPB}$ as a result of falling commodity prices (Ministry of Finance 2020). They form an impactful the crisis on the health, political, social, and economic sectors had an extraordinary domino effect. It can be ascertained that the state needs other instruments apart from taxes and additional state debt as a stimulus for the economic system.

Indonesia, as the largest Muslim majority country in the world, has great potential in Islamic financial instruments, both in zakat, infaq, shodaqoh and endowments. As a study conducted by the Center for Language and Culture of UIN Syarif Hidayatulloh (2009), the potential for zakat in Indonesia reached 19.3 trillion or equivalent to $0.8 \%$ of GDP in 2004 . Firdaus (2012) found that the potential for zakat in Indonesia reached Rp. 16,2 billion or the equivalent of $3.4 \%$ of Indonesia's GDP in 2010. Furthermore, in 2019 research conducted by BAZNAS showed 
that the potential for zakat funds was at IDR 21.3 billion. Beik (2009) stated that this zakat fund can be optimize as a tool to reduce poverty and inequality in the economy. The potential for this Islamic social financial instrument can be used as a supporting system state fiscal a countermeasure for the impact of COVID19 both in the health, social and economic sectors of the community.

The model of zakat distribution in restoring economic conditions is a matter that should be prioritized in facing this new normal. Therefore, the authors in this paper aims to formulate an innovative business model for community empowerment as an effort to overcome the impact of the economic crisis of society in the real sector, especially in maintaining the existence of small and medium enterprises (SMEs) as the backbone of the people's economy. Empowering SMEs affected by COVID using a business incubation model with analysis approach is Logical Framework Analysis (LFA)expected to provide more significant changes to the social and economic welfare of communities affected by the COVID-19 pandemic.

\section{LITERATURE REVIEW}

This research is a complementary to previous studies which have the same theory and problems. Talking about the Incubation Business Model Based on Productive Zakat in Post-Covid Economic Recovery.

\section{Effectiveness of Productive Zakat}

Nafiah (2015) defines productive zakat as a form of zakat given to mustahik as capital to carry out economic activities with the aim of increasing mustahik productivities and their daily income. Zakat should not only be used for consumptive needs, but also should be used as a source of funds for the people. According to Wafa (2011) stated that productive zakat is intended to finance mustahik in their business sector which can provide added value and increase their income. In line with this research, the researchers raised a business incubation model formulation that aims to alleviate economic problems for Micro and Small Enterprises (SMEs) affected by the COVID-19 pandemic.

Kholila (2016) in her research results states that optimization of zakat is closely related to how it is distributed. This condition can occur because if the distribution of zakat is right on target and in the right way it will be able to optimize the function of the utilization of the zakat fund. As in UU no. 23 years 2011, concerning Zakat Management which states the procedures for the utilization of zakat in clause 27, including:

1. Zakat can be utilized for productive efforts in the context of handling the poor and improving the quality of the people.

2. The utilization of zakat for productive business as referred to in paragraph (1) shall be carried out when the basic needs of the mustahik have been fulfilled.

The development of programs in community development that have been carried out by LAZ and BAZ can be allocated in the form of business capital, productive tools, training and also distribution of funds with the qardh hasan contract. According to Alim (2015) zakat funds are distributed to zakat recipients for venture capital and to help them increase their income. This scheme is classified as productive zakat. Meanwhile, according to a study conducted by Sukesti (2018) it is confirmed that the provision of productive zakat has a positive and significant effect on the development of SME businesses. The study conducted empirical evidence that productive zakat can bring changes to mustahik to increase growth, blessings and develop SME businesses. Distributing zakat as productive zakat to encourage SMEs to work optimally and get adequate results. Through productive zakat, 
mustahik do not only receive zakat only to fulfill their needs, but also to improve their welfare and make them more independent in various aspects.

\section{Mustahik Business Development Indicators}

Business development is a business activity carried out by means of entrepreneurship. The definition of mustahik business development is the distribution of zakat funds in the form of providing venture capital directly to mustahik. The distribution of zakat funds is directed at productive economic efforts, it is expected that the results will increase the level of community welfare or the efforts that have been made have an impact on progress and to further advance their business development in the future (Fuadi, 2019).

Jalaludin (2012) stated that the level of success of a business can be seen from sales growth and revenue growth, as a measure of company success. Sales and revenue growth is related to the turnover of business capital. Business capital is the company's financial ability to increase revenue. Thus, venture capital is also an indicator of business development. Studies related to the utilization of productive zakat funds state that the indicators consist of business capital, sales growth, income growth, increasing number of consumers, feeling safe with business continuity and increasing business profits.

Studies related to the utilization of productive zakat funds state that the indicators consist of business capital, sales growth, income growth, increasing number of consumers, feeling safe with business continuity and increasing business profits. Meanwhile, Hanum's study (2019) stated that the development of community empowerment based on productive zakat in its implementation is very close to the concept of Logical Framework Analysis (LFA), Participatory Rural Appraisal (PRA), and Parcipatory Learning Action (PLA). Logical Framework Analysis, which is an approach that commonly used by NGOs in their empowerment programs.
The logframe can be used as a tool that makes it easier to classify indicators of project success, program activities, forecast risks, goals, and outputs.

\section{Business Incubator}

According to Agustina (2011) defines a business incubator as a strategic alternative in created new entrepreneurs because it is more individual, integrated coaching techniques and operations in accordance with the stages of development faced by new entrepreneurs during the early period start-up. According to Septiana Ayu (2015) business incubators have a very strategic role in developing innovative MSMEs, through the incubators and technology-based entrepreneurial candidates can improve their performance and capacity. This is not only limited to the four universities that have initiated it, but can also be developed in universities, private institutions and other government agencies.

Meanwhile, research conducted by Hasbullah (2014) concluded that the implementation of the incubation program should be done multi years (2-3) years, so that it requires the main stakeholders to carry out the incubation program. Improving the quality of MSMEs through business incubators is considered very effective. The formulation used in the incubation model should be prepared based on tenant needs, so that the planned program runs more effectively and is right on target. The incubation model reference accommodates the incubation design that is bottom-up not merely top-bottom, to suit the needs of the incubator manager and the assisted MSMEs.

\section{METHODS}

This research is a qualitative research with a descriptive type. Based on Soekanto (2016), qualitative descriptive research is a problem-solving process by describing the state of a subject or object. This paper is not testing hypotheses but is trying to present an overview of a community-based business model with an empowerment 
scheme of productive zakat fund management aimed at restoring communities economic after the impact of the COVID-19 outbreak. The description of the business model will be illustrated through the social model schema innovated by the author.

According to Suwartono (2014) in his book entitled Dasar-Dasar Metodologi Penelitian reveals that the grouping of research approaches in general is very diverse and in this research the research approach used is to use case studies. Stake (1994) states that case study research aims to reveal the peculiarities or uniqueness of the characteristics contained in the cases studied. According to Yin (1994) divides case studies into explanatory and exploratory case studies. In this study, the researcher uses case explanatory study, which is a complex case study used in a causal study and uses a pattern matching system. In this case, the matching of a business incubation model based on productive zakat empowerment with a pilot project at SMEs Tutas Maes, which is one of the beneficiaries in the field of economic empowerment, Dompet Dhuafa Yogyakarta.

The data collection techniques used by researchers are primary data and secondary data. Primary data is carried out through interviews with beneficiaries as leaders in the business incubation project that has been carried out, while secondary data is from the review of business documents of research objects and study literature. After the data is collected, the data then processed by the researcher entering the analysis stage. According to Raharjo (2017), in essence data analysis is an activity to provide meaning or interpret data by arranging, sorting, grouping, coding or marking, and categorizing it into parts based on certain groupings. So, that a finding is obtained on the formulation of the problem proposed.

\section{RESULT AND DISCUSSION}

Based on data from the Ministry of Finance (2020) as a result of the COVID-19 outbreak, the country's fiscal condition has decreased by up to $10 \%$. Indonesia as a Muslim-majority country in the world has another instrument outside of the country's fiscal income instrument, called zakat. Irawan, et.all (2017) in their research concluded that zakat can positive significantly increase mustahik income. Qonita (2015) conducted a case study research at BAZIS DKI Jakarta which then showed that the distribution of zakat funds was proven to reduce poverty levels and the mustahik gap. Muslihah (2016) and Widyaningsih (2016), the results of their research also show similar results even though they have different objects of study, Widyaningsih (2016) measures the impact of zakat in South Sulawesi while Muslihah (2016) studies the case on LAZ PM AI. The results of both studies present that the distribution of zakat funds can improve the welfare of mustahik households and reduce poverty.

Zakat institutions have played an active role in fighting against the crisis conditions caused by this pandemic. Based on the Policy Brief published by Puskas BAZNAS (2020), BAZNAS as the only government amil zakat organization on a national scale, there are several sectors where zakat has contributed, that are education, health, preaching, social and humanitarian. Zakat has taken on various roles, although the proportion of traditional or consumptive zakat distribution can be said to be more dominant. The main purpose of distributing zakat using this model is to help mustahik from poverty and fulfill their basic needs especially during the pandemic crisis (Hanum, 2019), but according to Retsikas (2014) stated that zakat is not just a religious activity, more than fundamental instrument to achieve social economic. Social economic equality must be encouraged by the independence of the community in carrying out a more 
productive cycle of economic activities. Therefore, in this study the researchers will focus on presenting zakat distribution formula in the economic sectors by empowering new mustahik caused by the weakness global economic growth due to COVID-19-based community (community) with the incubation technique.

\section{Model Scheme for Business Incubation Empowerment}

The distribution of zakat based on community development both the Amil Zakat Institution (LAZ) and the National Zakat Agency (BAZNAS) can be said to be a renewable model in the distribution of zakat funds. As in Hanum's research (2019) since 2011 BAZNAS has been played an important role in establishing the latest policies regarding the utilization of zakat. BAZNAS adopts a model community driven development by making benchmarking on several LAZ that have started earlier. According to Fauzia (2017) LAZ is the main actor contributing to the modernization of zakat practice for social justice. They have transformed traditional zakat practices that are deemed ineffective to empower poverty into an independent economic. The traditional model that was previously more familiar to use the method, direct cash either in the form of money or goods that are ready for consumption. Whereas in the distribution of zakat based on community development, funds are distributed in the form of reallocation capital as the empowerment of mustahik through several stages.

The role of zakat development based on community empowerment is the right step in elevating society to the level of self-empower. This has been proven through LAZ Dompet Dhuafa's steps which started a community empowerment-based zakat utilization program in early 2000 s and then solidified its work by forming Karya Masyarakat Mandiri (KMM) in 2005. Dompet Dhuafa's success in alleviating poverty through empowerment programs then made it a pioneer and this inspired BAZNAS for released a similar program called Zakat Community Development (ZCD) in 2011. The success of community development is prompted the author to improvise and innovate existing programs into community-based zakat utilization programs as a recovery in post-COVID-19 economic conditions through the scheme in the Figure 2.

CASE STUDY DUCK FARM

ZAKAT COMMUNITY DEVELOPMENT FOR SMES MODEL BASED ON BUSSINESS INCUBATION

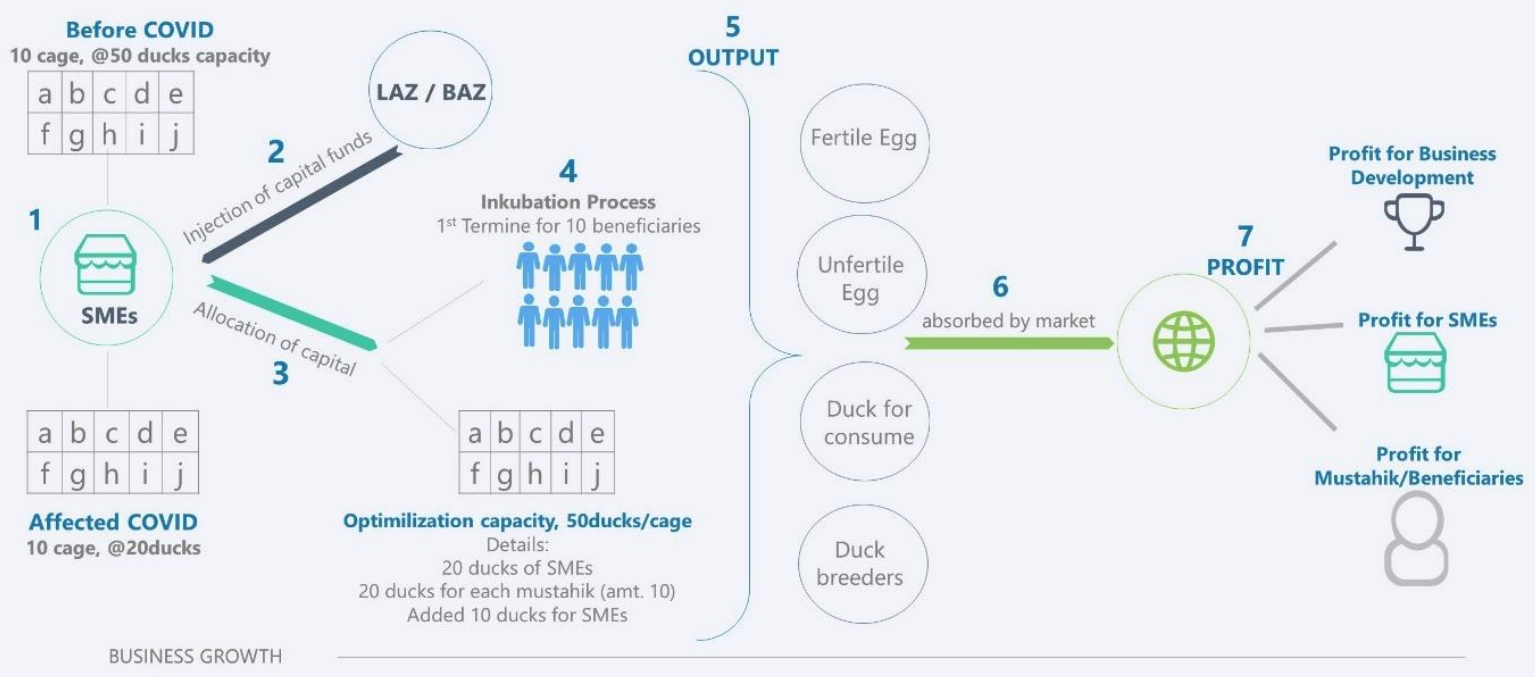


Figure 2. Business Incubation Model Based on Productive Zakat for SMEs Economic Recovery of Post COVID-19

Description

1. The first stage describes the conditions of a business before the pandemic outbreak and after being affected by COVID-19. In the above model scheme, SMEs engaged in duck farming, for example, initially had 10 cages with a maximum capacity of 50 ducks. After demand market decreased, income has decreased while maintenance costs such as feeds, vitamins, and cages maintenance must continuously to cover the economic needs by SMEs selling duck derivative products and reducing cages capacity. So that, it has an impact on the number of ducks that were originally $50 \mathrm{x}$ 10 cages equal to 500 ducks, but now they only 200 ducks.

2. In the second stage LAZ and BAZ can be capital injection for SMEs affected by COVID, both with the conditional grant scheme and Qardhul Hasan. The main purpose of distributing zakat, infaq and shodaqoh (ZIS) funds is for business recovery. In addition, in this empowerment program, SMEs, as well as adequate efforts of skill and capacity, must be able to empower several mustahik around their environment.

3. The next stage, the funds that have been received by SMEs from BAZ / LAZ are allocated into several allocation posts. That is including supporting the acceleration of business facilities, feed, and also seed capital for mustahik and additional seeds for the UMK itself.

4. In the fourth stage, the incubation process is carried out where all livestock are centered and incubated in the drums that already available at SMEs. In the other Hand from the limited facilities owned by mustahik start-up new entrepreneurs, this process will be help in creating quality livestock ecology depend on the standards. before that, they developed more broadly. Then the incubation process is not only intended for business objects, where in this case study duck livestock, but also for mustahik who do not have the capability in this business field. These prospective entrepreneurs will receive an incubation process for several periods with direct training and mentoring by experts and practitioners who have been successful in that business, they called
UMK. Learning activities are divided into three main activities, that are theoretical in class, group discussion and the last is practice on field.

5. The fifth stage is the output of the business that run. No matter business that been carried out after the process in certain period will produce output that can be accepted by the market and achieve the company's goals, called profit and maslahah. Whereas in this case study of duck farming, there are several derivative products of duck itself that can be traded and offered in the market, including nonfertile duck eggs (both raw and salted eggs), superior breeding eggs, bayah (young ducks), and duck breeders.

6. The sixth stage is the market absorption stage, where the sales mechanism remains centralized in SMEs that previously have business network relationships. In addition, the scheme model will protect the balance of prices and create an environment for mutual cooperation for good results in the community

7. And the last stage after the sale is to obtain profit which can be allocated to several fund flow posts, namely capital turnover to enlarge / make them independent, additional income for SMEs and mustahik, and reach maximum market absorption with more innovation in creating derivative products unique and needed by the market.

Optimizing community empowerment with the concept of community basically has 6 types of main activities that must be fulfilled, they are: 1) Planning, 2) Assessment of mustahik needs and market demands, 3) capacity building, 4) Asset reform, 5) Assistance by facilitators (LAZ / BAZ), and 6) Program monitoring and evaluation.

In the community-based empowerment model scheme above, zakat funds are not distributed at one time, but require several terms in a certain time scale of several years. The injection of funds in the following terms will be allocated if the achievement of the program has fulfilled the qualification targets, both in terms of 
increasing the number of mustahik, progress of business activities, etc. After SMEs are empowered, the focus of zakat utilization can be optimized in expanding mustahik plasma and increasing mustahik plasma capacity to become SMEs and muzaki. And so on, the plasma community program environment is expected to be sustainable in providing its benefits.

\section{Analisis Logical Framework Analisys (LFA)}

Empowerment society based on community program is in the early stages of planning and needs assessment, adapting the concept of the Logical Framework Analysis or commonly known as LFA. LFA is an analytical tool originating from USAid since 1960 which is used as an empowerment project development by NGOs (Center for International Development and Training 2002). Based on research conduct by Hanum (2019) Using Logical Framework analysis will make it easier to manage community-based empowerment activity programs to achieve the desired goals. This concept has been adapted by Islamic philanthropic institutions both BAZ and LAZ in utilizing their productive zakat.

The concept of LFA analysis is often used based on the law of cause and effect which tends to be easily understood by the various stakeholders concerned. In addition, the concept of the community approach in LFA used the concept of participatory rural appraisial (PRA), namely approaches or techniques for community involvement in thought processes that take place during planning, implementation, monitoring and evaluation of community development programs (Satrio 2019). In short, the concept of this method can be defined as a method used in conducting studies to understand village conditions by involving direct community participation. Through this technique, this approach gives a more real role to the community / society to analyze their problems and needs in designing a program to be sustainable and so that it is no longer dependent on outsiders. Likewise, in the business model scheme presented in this paper, the main strength that must be brought into the program is the potential of SMEs and the surrounding community who open to be empowerment.

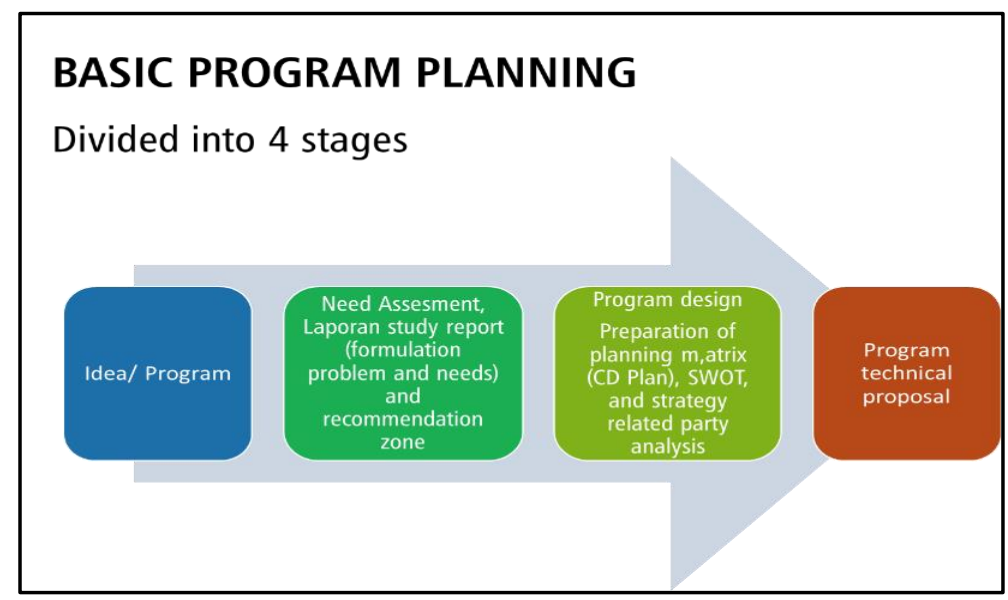

Figure 3. First Step for LFA Analisys (Satrio 2019)

Logical Framework Analisys (LFA) driven from problem identification which resulted and started through an analysis of the four initial stages in planning they are:
1) Program ideas / ideas $\rightarrow$ which in this case is empowerment with a business incubation model 
2) Assessment, formulation of problems \& needs with PRA (active community participation) $\rightarrow$ approach techniques highly dependent on regional conditions, culture, and the potential of the community subject to empowerment.

3) Program design through the preparation of a planning matrix, one of them is problem analysis and strategy analysis $\rightarrow$ in this case it is carried out jointly by all relevant stakeholders, including SMEs, communities, BAZ / LAZ, and local governments.
The problem is a negative condition that affects the target group. A good problem statement has several indicators including (Satrio 2019):

a) Describe a situation that requires change

b) mention 'who and what' should be changed

c) Quantifying the problem (how many)

d) Answering an issue related to the objectives of the institution

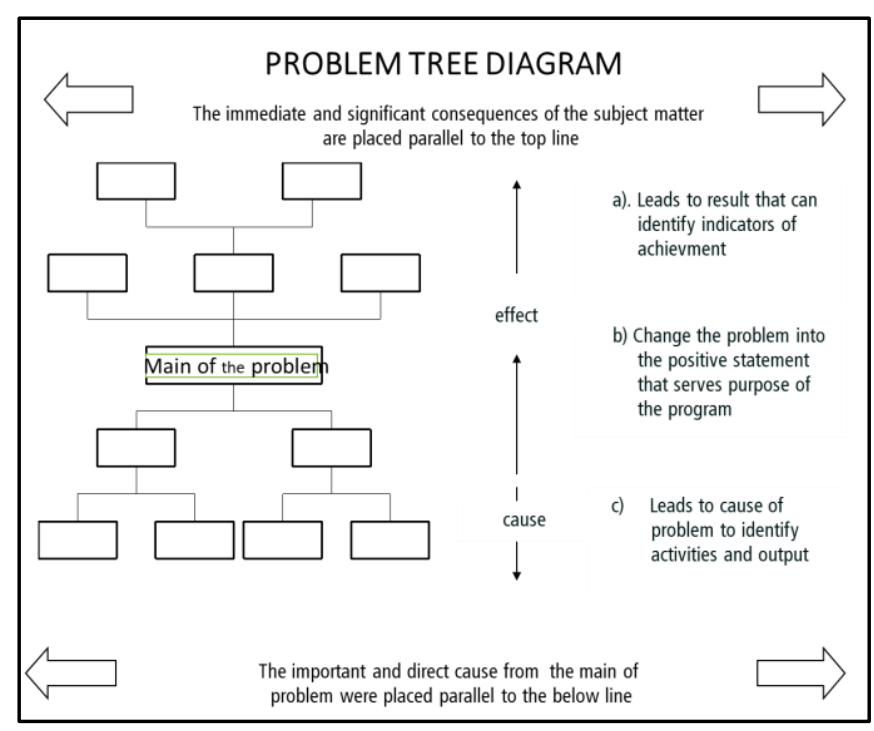

Figure 4. Problem Tree Diagram (Satrio 2019)

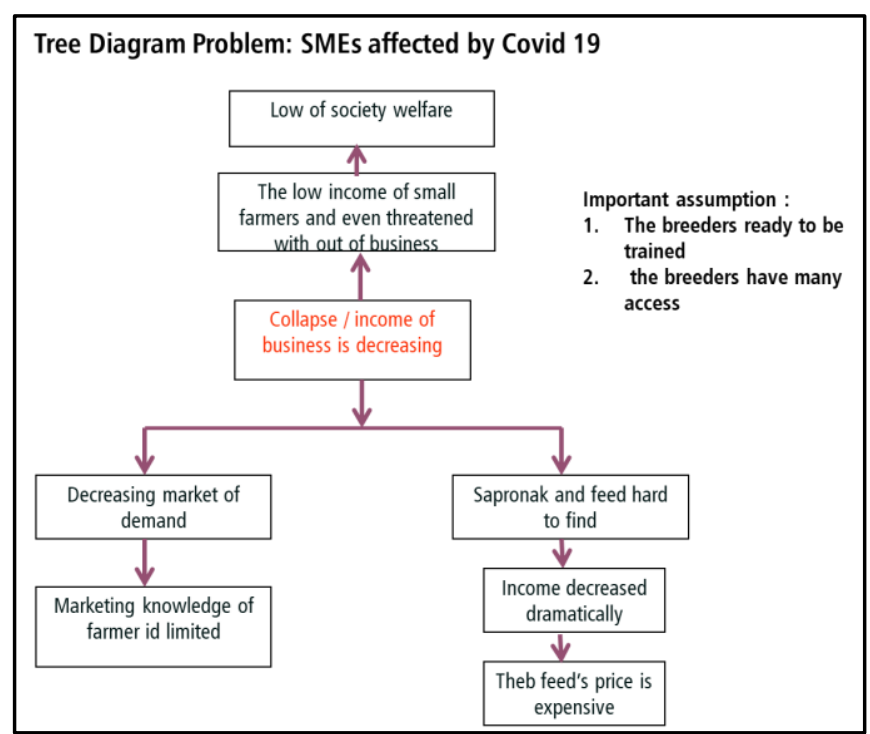

Figure 5. Tree Diagram Analysis Problem of SMEs Duck Farm (Processed Data, 2020) 
A program generally departs from a problem at hand to find a solution. The program appeared because of a problem. This does not mean that every problem has to give rise to the program. There are many ways and techniques to identify, explore and find problems. One of the methods of extracting or identifying problems is the Tree Analysis problem. Figure 5 shows a brief example of the Tree Analysis problem from a case study of duck farming SMEs affected by COVID-19.

The formation of this tree analysis problem is a step in making the Program
Planning Matrix (MPP) which has the aim of assisting the process of formulating strategic objectives to be achieved (GOAL), specific goals (PURPOSE), actions that need to be implemented, performance indicators and verification tools for monitoring \& evaluation of programs, assumptions or risk indicators that need to be considered in order to achieve goals (high, medium, low). This formula is adopted by a standard logframe. The following template (Table 1) is a standard table in the Logical Framework analysis.

Tabel 1. Standart Logframe Template

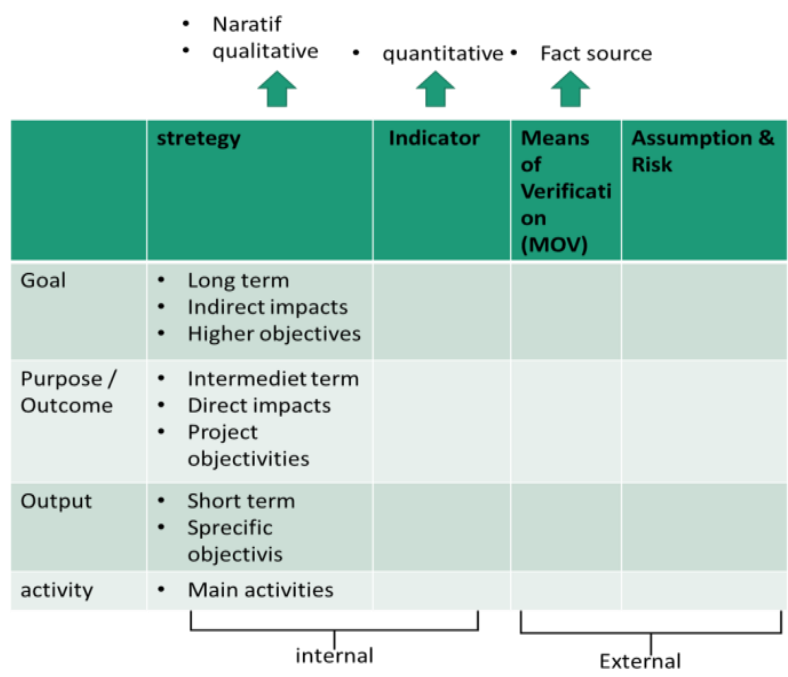

4) After the analysis of the problems, needs, SWOT, has been summarized in the Program Planning Matrix (MPP) document, the final step is a technical proposal for appropriate program submissions based on various analyzes that have been carried out.
After analyzing step by step to the process, then we can generate the program goal tree. The following case study is a description of the tree analysis of the objectives of empowering duck SMEs affected by COVID (Table 6). 


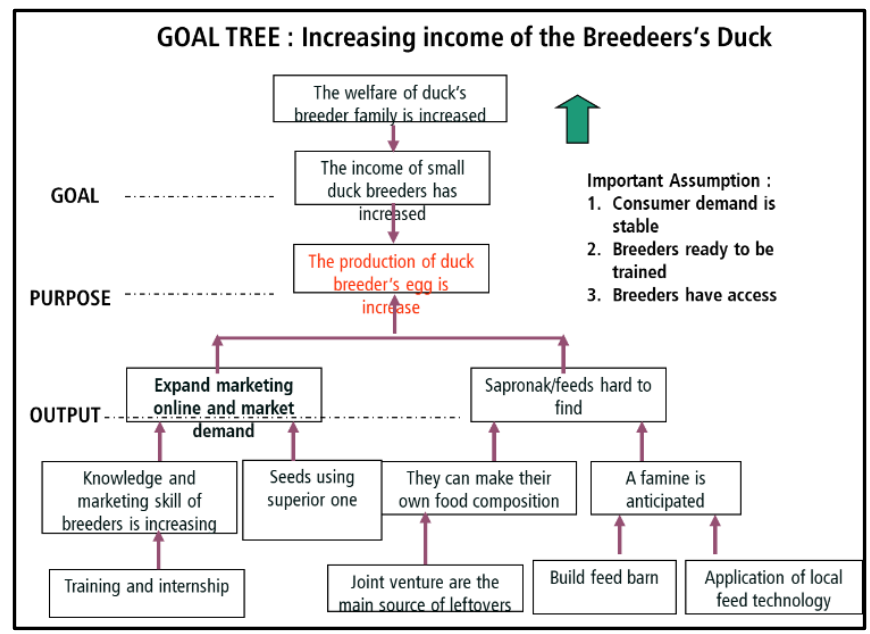

Figure 6. Goal Tree analysis, Case study: SME’s Ducks's Breeders Farm (Processed Data, 2020)

Optimizing community empowerment with the concept of community basically has 6 types of main activities that must be fulfilled, they are: 1) Planning, 2) Assessment of mustahik needs and market demands, 3) capacity building, 4) Asset reform, 5) Assistance by facilitators (LAZ / BAZ), and 6) Program monitoring and evaluation. In the community-based empowerment model scheme above, zakat funds are not distributed at one time, but require several terms in a certain time scale of several years. The injection of funds in the following terms will be allocated if the achievement of the program has fulfilled the qualification targets, both in terms of increasing the number of mustahik, progress of business activities, etc. After SMEs are empowered, the focus of zakat utilization can be optimized in expanding mustahik plasma and increasing mustahik plasma capacity to become SMEs and muzaki. And so on, the plasma community program environment is expected to be sustainable in providing its benefits.

\section{CONCLUSION}

Utilization of productive zakat by using community empowerment schemes has enormous potential in restoring the economy of people affected by COVID- 19 . It has been shown by the achievements of BAZ and LAZ in the previous period in implementing this empowerment model. On the other hand, the author has offered innovations in the development of community empowerment based business incubation programs that can provide multiplier effects not only affected Micro and Small Enterprises (SMEs) but also on other layers of society or other mustahik. This scheme is expected not only for SMEs recovery and be able to become muzaki, but other mustahiks also expected to do so.

\section{REFERENCE}

Ascarya, 2020. The Role Of Islamic Social Finance in Times of COVID-19 Outbreak, Bogor: s.n.

Ayu, W., 2020. Memahami Dampak Lockdown Bagi Perekonomian Indonesia, Jakarta: Universitas Indonesia.

Beik, I. S., 2009. Analisis Peran Zakat dalam Mengurangi Kemiskinan: Studi Kasus Dompet Dhuafa Republika. Jurnal Pemikiran dan Gagasan, 2(1), pp. 1-11.

Fauzia, M., 2017. Economic Estimation and Determination of Zakat Potential in Indonesia, Jeddah: IRTI Working Series. 
Firdaus, M. B. I. d. I. T., 2012. Economic Estimation and Determinations of Zakat Potential in Indonesia, Jeddah: IRTI Working Paper Series, Islamic Development Bank.

Hanum, K., 2019. Zakat Based Community Driven Development: COgnition Development in The field of Zakat Practice in Indonesia. IJAZ, 4(2), p. 4.

Isro'iyatul Mubarokah, I. S. B. \&. T. I., 2017 . Dampak Zakat terhadap Kemiskinan dan Kesejahteraan Mustahik (Kasus : BAZNAS Provinsi Jawa Tengah). Jurnal Al-Muzara'ah, 5(1), p. 49.

Kemenkeu, 2020. fiskal.kemenkeu.go.id. [Online]

Available at:

https://fiskal.kemenkeu.go.id/dw-

konten-

view.asp?id=2020040210175171756

$\underline{8528}$

[Accessed 08 June 2020].

KEMENKOP, 2018. Perkembangan Data Usaha Mikro, Kecil, Menengah (UMKM) dan Usaha Besar (UB) Tahun 2017-2018, Jakarta: Departemen Koperasi.

Maulana, N., 2019. The Business Model Canvas (BMC) PenggunaanBMC dalamPerancanganProgram PemberdayaanDesaBerbasiskanKew irausahaan, Bogor: Dompet Dhuafa University.

OECD, 2020. SME Policy Responses of COVID-19.

[Online] Available at: https://read.oecdilibrary.org/view/?re $\mathrm{f}=119$ 119680di6h3qgi4x\&title $=\mathrm{Co}$ vid19_SME_Policy_Responses [Accessed 08 June 2020].

Puskas BAZNAS, 2020. Puskas Working Paper Series (PWPS). Pembangunan Ekonomi Sosial Berbasis Wilayah dalam Kasus Pembatasan Sosial akibat Krisis Covid-19 Indonesia 2020, March, p. 5.
Puskas BAZNAS, 2020. THE ROLE OF ZAKAT INSTITUTION IN PREVENTING COVID-19. POLICY BRIEF MARCH 2020, MARCH, p. 5.

Retsikas, K., 2014. Reconceptualing Zakat in Indonesia: Worship, Philantrophy and Rights. Indonesia and The Malay World, 42(124), pp. 337-357.

Training, C. f. I. D. a., 2002. A Guide for Developing a Logical Framework, Birmingham: University of Wolverhamton.

Nadia Nuril Ferdaus

Postgraduate School

Gadjah Mada University

nadia.nuril.ferdaus@mail.ugm.ac.id

Ahmad Hidayatullah

Istanbul Sabahattin Zaim University

hidayatullah.akademik@gmail.com

Fatimatuz Zahrati

Postgraduate School

Gadjah Mada University

Fazazahrati620@gmail.com 